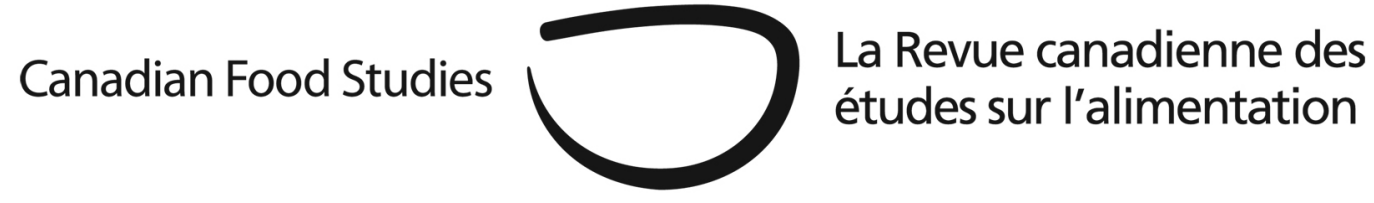

Review Article

\title{
New CSR in the food system: Industry and non- traditional corporate food interests
}

\author{
Margaret Bancerz \\ PhD candidate, Policy Studies, Ryerson University \\ mbancerz@ryerson.ca
}

\begin{abstract}
Throughout the twentieth century, the food system has not only undergone changes in structure and in process, but has also shown a growing transformation in food system governance. Often this transformation involves private actors engaging in the policymaking and governance arena. This paper draws on corporate social responsibility (CSR) as a private governance mechanism that is frequently used by corporate food actors. The rise of industry's participation in non-traditional corporate food interests (NTCFIs), or social and environmental concerns, will be explored by drawing on changing governance structures in the food system. NTCFIs move beyond traditional interests of corporate actors such as trade, economic regulation, and competitiveness, and reach into social and environmental issues found in the food system that are often a result of agri-food production and its business practices. This paper problematizes the increased CSR of corporate actors in social and environmental issues in the food system. It considers both sides of the debate: an optimistic view of business engaging in NTCFIs, and a more skeptical view. It concludes with a third, middle ground view, stating that given the power and resources of corporate food actors, industry should be involved in food system change at arm's length in a tripartite partnership: civil society, government, and the corporate sector.
\end{abstract}

Keywords: food industry; corporate social responsibility; non-traditional corporate food interests; food governance 


\section{Introduction}

\section{“... [T] he large corporation has become the most important new political} institution in the contemporary political order" (Mitchell, 1986, p. 208).

The twentieth century saw a transformation in the way food was produced, distributed, consumed and controlled, with multiple consequences for policy and governance (Lang, 2003). This changing food system was characterized by a progression of complex health, social, and environmental crises, signalling a need for new mechanisms of governance. One result was the emergence of a dual governance comprised of various public and private actors as well as international organizations (Havinga, van Waarden, \& Casey, 2015), creating a state-led regulatory system, and a self-regulatory system (Havinga, 2015; Lang, 2003). Scherer, Palazzo, and Matten (2014) argue that the involvement of non-state actors in policymaking is a relatively new phenomenon, developing from politico-economic changes produced by globalization in the 1980s and 1990s. They argue that the politico-economic changes displaced the traditional powers of the state, leaving certain regulatory and policy vacuums, often in areas that have become privatized or are transnational and "wicked" in nature.

Under these circumstances, private actors are seen by some as stepping in and behaving as political actors (Scherer, Palazzo, \& Matten, 2014), developing private governance in various ways such as corporate social responsibility (CSR), standards, and certifications (Fuchs, Kalfagianni, \& Havinga, 2011). In the food system, corporate political involvement through private governance is seen in public health issues in the food sector (Sharma, Teret, \& Brownell, 2010), food safety (Havinga, 2006), environmental management and animal welfare on the farm (Richards, Bjørkhaug, Lawrence, \& Hickman, 2013), as well as supply chain management (Burch \& Lawrence, 2005; Fuchs \& Kalfagianni, 2010; Hatanaka, Bain, \& Busch, 2005).

The purpose of this paper is to explore different perspectives concerning the engagement of corporate food actors in CSR to better understand industry's involvement in political, social, and environmental issues in the food system. I draw on CSR in particular as a private governance mechanism, and as a way in which the firm becomes a political actor (Scherer \& Palazzo, 2011; Scherer, Palazzo \& Matten, 2014) that is willing to engage in and undertake "political responsibilities" in areas of human rights and the enforcement of standards (Castelló \& Lozano, 2011). I argue that there is an increased tendency for the private sector to get involved in the policy and governance process through what I call nontraditional corporate food interests (NTCFIs). These are concerns that move beyond traditional interests of corporate actors that were the foundation of the older CSR (described below) such as trade, economic regulation, and competitiveness.

Examples of NTCFIs can be initiatives around healthy food, food security, animal welfare, local food, and other social and environmental issues. The current CSR practised by corporate food actors is based on industry developing alternative policies and programs for NTCFIs. This becomes a confusing governance phenomenon when the private sector begins engaging in concerns many see as being created through their production and corporate 
business models. Some look at industry's involvement in these issues skeptically, as a form of greenwashing and gaining legitimacy. Others argue that this is a new and important step towards corporate citizenship and social responsibility of industry.

This article examines that debate and demystifies the new development of food companies incorporating social and environmental policies into their corporate priorities. I begin by briefly discussing CSR as a concept, and then by exploring NTCFIs in more depth, with a few specific examples. Then, borrowing some analytical tools from the business management discipline, I analyse both sides of the debate regarding corporate political involvement in NTCFIs, beginning with the optimistic perspective. This is followed by a third view of CSR and corporate engagement in food system change, drawing on the idea of a multi-stakeholder partnership. I conclude by summarizing the outcome of the debate, and calling for more empirical research on CSR and the food industry.

\section{Corporate social responsibility (CSR)}

There are many different types of CSR. Auld, Bernstein, and Cashore (2008) identify seven types of which some include standards, codes of conduct, and private sector hard law such as the Marine Stewardship Council. CSR, is defined very broadly by Windsor (2006) as a way in which firms should deal with public policy and social issues. This behaviour goes beyond what is required by law and the market (Auld, Bernstein, \& Cashore, 2008). There is no single formula as to how CSR can be carried out. In fact, there is no consensus in the literature on its very definition (Chandler, 2014; Freeman, Harrison, Wicks, Parmar, \& de Colle, 2010), however each definition shares the common idea of expanding the duties and responsibilities of business beyond financial matters (Freeman et al., 2010).

Recently authors (Auld, Bernstein, \& Cashore, 2008; Castelló \& Lozano, 2011; Scherer \& Palazzo, 2011) have been identifying differences between an older and newer version of CSR. Older CSR practices largely consisted of corporate philanthropic activities, for the most part, unrelated to the core practices of the organization (Auld, Bernstein, \& Cashore, 2008). Castelló and Lozano (2011) find that new CSR engages with stakeholders more than the old one. New CSR involves a firm's engagement in the promotion of social and environmental standards through modifying its core practices and internalizing negative externalities, rather than deflecting them (Auld, Bernstein, \& Cashore, 2008). It engages in specific environmental and social activities which in the past tended to be the responsibility of government (ibid), making it more political than the old CSR. In this paper, I will be referring to new CSR which includes a combination of Auld, Bernstein, and Cashore's (2008) types of CSR outlined above.

Food industry's involvement in non-traditional corporate food interests (NTCFIs)

The growing number of food industry actors engaging in NTCFIs through CSR is becoming increasingly visible on many levels. Specific examples of business engaging in NTCFIs can 
be found within individual firms. There are abundant examples of companies engaging in NTCFIs on their own, but for the purposes of this paper, I will focus on two popular governance areas: animal welfare, and food literacy.

Animal welfare initiatives have been most popular in fast food chains shown through efforts to source more "humanely produced" meat products. A recent wave in the fast food world has centred on the elimination of gestation crates for pigs and battery cages for hens. Several fast food chains are engaging in new animal welfare initiatives including Wendy's, McDonald's, Burger King, and Chipotle, for instance. Wendy's promotes an animal welfare program outlined on their website with guidelines on the use of antibiotics, and how animals producing beef, chicken, and pork meat products for Wendy's should be housed, transported, handled, and unloaded. Similarly, McDonald's US announced in 2012 that by 2022 it would no longer source pork from producers that use sow gestation crates (Huffstutter, 2012; McDonalds, n.d.). In the same year, Burger King vowed to end egg sourcing from producers using battery cages, and only source pork from producers who are working to eliminate gestation crate practices (Baertlein, 2012).

Many other companies are also jumping on board the animal welfare bandwagon. Perhaps the biggest animal welfare effort comes from Chipotle, with an animal welfare initiative intertwined with their overall food sourcing strategy. The initiative has a general approach identified by the company as "food integrity”, outlining various ways in which the company sources ingredients for their products. On their website, they state: "Chipotle is seeking better food from using ingredients that are not only fresh, but that — where possibleare sustainably grown and naturally raised with respect for the animals, the land, and the farmers who produce the food" (Chipotle, 2015, p.13). Chipotle is also making efforts to shorten their supply chains by sourcing ingredients from local farms. Many of their NTCFI initiatives are featured in videos on YouTube showcasing the producers and farms from which Chipotle sources its products. Several of these videos deconstruct the ideas and practices behind industrial farming, some even featuring farmers denouncing it. One of Chipotle's big animal welfare campaigns emphasized sourcing pasture-raised animals without nontherapeutic antibiotics and synthetic hormones.

Other food companies have been focusing on "food literacy", that is, encouraging and educating its consumers on how to eat and prepare fresh and healthy food. In addition to animal welfare initiatives, Chipotle has been actively engaging in educating consumers about the food system. It does this through storytelling online as well as through its Chipotle Cultivate Foundation (Chipotle, n.d.). Canadian grocery store chain Metro has rolled out a healthy food literacy program called My Healthy Plate, partnering with experts like dieticians and academics. Metro's dietitians have created a smile label that is used in-store to inform the consumer whether a product is a "good" or "great" choice. As a result, consumers do not have to study the nutrition labels while shopping (Metro, n.d.a.). Recipes are also provided on Metro's website highlighting the use of unprocessed ingredients to increase the nutritional value of the food consumers eat. Four pillars outline their program: "[To] [i]mprove our product range to promote healthy eating; help our customers select healthy food products; provide access to healthy products at affordable prices; and promote healthy eating habits in the community" (Metro, n.d.b). In addition to this, in the summer of 2014, Metro created its 
own food truck that travelled across ten Québec festivals showcasing local Québec food, recipes using local foods, and local store owners (Kashty, 2014).

In 2013, Sobeys partnered with celebrity chef and food literacy activist, Jamie Oliver, in its Better Food Movement campaign. Jamie Oliver makes regular appearances on Sobeys' YouTube channel, with announcements, recipes, or promotions for products, like Sobeys' certified humane meat. Sobeys website states: "Jamie Oliver is working with us to champion enhanced food knowledge, balanced nutrition, quality ingredients, and cooking skills for Canadians” (Sobeys, n.d.). There are also many recipes and links with social media campaigns having to do with particular food ingredients or seasons.

Similarly, in 2007, Hellmann's, a Unilever owned mayonnaise company, launched the Real Food Movement which is also a food literacy initiative. Hellmann's states that it started the initiative to "help Canadians connect with and understand the delicious benefits of real food” (Hellmann's, n.d., p. 2). They have “...developed toolkits, guides and interactive recipes to help families realize how easy it can be to bring more real food to their tables" (ibid). With the campaign's launch, Hellmann's developed a grant program that funds initiatives to help educate children in food and food preparation. In 2014, Hellman's set up the "Real Food Truck" at the Canadian National Exhibition in partnership with Chef Lynn Crawford of the Food Network, which sampled "real food" snacks featuring Hellman's mayonnaise.

While there are plenty of other examples of industry engaging in NTCFIs on various levels, this brief list has presented a handful of firm-level examples with animal welfare and food literacy initiatives, showing new ways in which companies are engaging in CSR in the food system. The following sections will introduce two perspectives that can be used to better understand industry's engagement in NTCFIs, as well as a third alternative approach.

\section{Corporate social responsibility: Optimistic perspective}

One perspective of CSR in the food system is an optimistic approach which stems from understanding changes in the state, and the increase in private governance through CSR. This means that CSR is viewed in a positive way, both for business and society. The reasons behind engaging in CSR are therefore constructive, genuine, and are based on the promotion of the well-being of stakeholders rather than solely on financial goals. This of course does not mean that financial considerations are ignored. Two major analytical approaches will be identified below: corporate citizenship (CC) and creating shared value (CSV). Other approaches will not be discussed here because they are not directly pertinent to industry engaging in socio-political behaviour. Some examples include corporate social performance which is a way to measure industry's involvement in socio-political issues; corporate political strategy which discusses plans to influence government policy to benefit industry competitiveness (Hillman \& Hitt, 1999); and stakeholder theory/management focuses on the firm's purpose, and its stakeholders beyond its shareholders (Donaldson \& Preston, 1995; Freeman et al., 2010). 


\section{Corporate citizenship}

In the past few decades, corporate actors have begun to take on activities largely regarded as state activities through self-regulation and the filling in of legal and governance gaps (Scherer \& Palazzo, 2011). This phenomenon is contextualized through the transformations in international political economy stemming from globalization as well as the resulting shifts in the role of the state, which by consequence, imply changes in governance (Bevir, 2012; Kennett, 2008; Peters \& Pierre, 1998; Pierre \& Peters, 2000). These changes come from “old government”, a hierarchal order of authority and administration vested in the state holding dominance in the policy process (Kennett, 2008), to new governance, where the state is only one of several players in the policymaking arena. This governing shift has blurred the boundaries between private and public actors and changed the nature of the policy process. Due to the state's decreased ability and/or willingness to govern in certain areas, new forms of governance arrangements beyond the state have been emerging (Scherer \& Palazzo, 2011), creating a shift from "government” to "governance” (Peters \& Pierre, 1998). This has also incited a growth in private governance expressed in industry's involvement in codes of conduct, CSR, private certification and labelling (Fuchs \& Kalfagianni, 2012).

Through the withdrawal of the state in particular policy areas, and the subsequent engagement of industry actors in them, corporate citizenship (CC) is a useful concept to use when trying to understand this governing shift. Carroll (1998) argues that CC is made up of four faces: economics, law, ethics and philanthropy. Therefore, good corporate citizens are expected to fulfill their economic responsibilities and be profitable, fulfill their legal responsibilities and follow the law, be receptive to ethical responsibilities, and engage in philanthropy. CC has been increasingly used by firms and in academia to rework facets of CSR (Moon, Crane, \& Matten 2005). Matten \& Crane (2005) and Matten, Crane, and Chapple (2003) find that definitions of CC like Carroll's (1998) are very similar, if not identical to CSR. As such, they provide an "extended" definition of CC considered in this paper, showing a shift in the role of corporate actors to a more political role in society.

They begin with the concept of "citizenship". When thinking of corporate actors as citizens in a literal sense, this implies that like every other citizen, they have rights, duties, and are citizens of the country in which they do business. Matten and Crane (2005) follow T.H. Marshall's definition of liberal citizenship as based on civil, political, and social rights. Civil rights include freedom from abuse, government intervention (negative rights), as well as the right to freedom of speech, and to own property. Political rights entail the person's active participation in society, such as the right to vote and hold office (Matten \& Crane, 2005). Lastly, social rights allow a person to participate in society, through education, healthcare and other forms of the welfare state.

Matten and Crane (2005) contend that the state is traditionally considered as the guarantor of liberal citizenship. However, with the changes in the role of the state and the retrenchment of the welfare state, corporate actors have been filling the vacuum left behind by the state and securing some of the rights of citizens under liberal citizenship. Thus, “'corporations' and 'citizenship' come together in modern society at the point where the state ceases to be the only guarantor of citizenship...” (Matten \& Crane, 2005, p.171). Three 
instances are identified in which the roles of managing citizenship are changing: (1) when government no longer carries out citizenship rights, (2) when government has not yet carried out citizenship rights, and (3) when the carrying out of citizenship rights may be beyond the reach of government. Drawing on these ideas, Matten and Crane (2005) redefine CC, as "...the role of the corporation in administering citizenship rights for individuals" (p. 173). The corporate actor is not so much a citizen as an actor standing in on behalf of the state, at times, to secure facets of liberal citizenship. Under CC, corporate actors tend to become guarantors of the social rights pillar of liberal citizenship (Matten, Crane, \& Chapple, 2003). Examples of corporate actors engaging in securing social rights, such as the right to (healthy) food for children, can include contributions and development of anti-hunger and healthy food programs in schools.

Drawing on the CC literature, industry engaging in NTCFIs can be seen as a way for corporate actors to engage in private governance through CSR efforts. If corporate actors are taking up the role of corporate citizen in the way that Matten and Crane (2005) and Matten, Crane, and Chapple (2003) are suggesting, then this development implies that corporate actors are in fact filling the state policy vacuum in the food system through securing social rights for citizens in the form of CSR. Different educational and environmental rights can be supported through corporate actors' CSR efforts, as seen through food literacy initiatives and calls for a more sustainable food system. Thus, thinking in terms of CSR as CC, a different system of governance in the food system may be emerging that will come to depend on private governance for NTCFIs, rather than on government stepping in to create food policy and secure social rights linked with the food system.

\section{Creating shared value}

Creating shared value (CSV) is another optimistic view of CSR. It was coined by Porter and Kramer in Harvard Business Review in 2006 in an article entitled "Strategy and society: the link between competitive advantage and corporate social responsibility”. Here the authors introduced a new business perspective that centres on the interdependence of business and society rather than on its tensions and argues for “anchoring” CSR in a company's business strategy.

Porter and Kramer (2011) maintain that CSV is viewed from a broader conceptualization of capitalism. Business is not seen positively in society due to the use of an outdated model of value creation. Value is often considered as a narrow subset of short-term financial successes which overlook changes that would support long-term success. Social and environmental issues have often been pinned against business success, treated and institutionalized as trade-offs between the well-being of society and the success of business. Neoclassical economists have structured the economy as a zero-sum game between society and business. Social contributions or improvements are seen as taking away from the successes and prosperity of business, raising costs of firms and decreasing profits. In contrast, shared value is based on the idea that traditional economic needs combined with societal needs make up the market. 
Often, working against societal needs hinders the productivity and success of a business through the creation of internal costs. However, CSV blends issues that have always been seen as trade-offs with the core business of a firm, and creates a new approach that fuses society and business. Thus, business value is created at the same time as societal value, hence the idea of shared value. This is an approach that lies at the very core of a business' everyday existence. However, Porter, and Kramer (2006) caution that corporate actors should only choose causes that are both a benefit to society and to their prosperity to best address some of the world's social issues (Porter \& Kramer, 2006). CSV is not about sharing an already created value or redistributing value and profit, but rather about expanding the value in both economic and societal spheres.

This value is created in three ways "by reconceiving products and markets, redefining productivity in the value chain, and building supportive industry clusters at the company's locations” (Porter \& Kramer, 2011, p. 67). The authors explain that by reconceiving products, industry increases innovation and creates products that are fundamentally necessary or useful for people, or relate to their top concerns. Many of the NTCFIs identified in the section above fall into this category. In the food system, this could be a product that is produced more sustainably, or a product that has more or less of a particular attribute (i.e. salt, sugar), or none at all (i.e. trans fat, antibiotics and hormones used in meat, etc.) that targets consumer health concerns. Products can also focus on consumer worries about animal welfare, labour concerns (fair trade compliance), and even one many Canadians now take for granted, food safety. Value in these cases is shared between consumers and companies where specific consumer concerns are being met, while increasing (or maintaining) the profit margins of a firm.

Second, redefining productivity in the value chain is crucial given that value chains affect and are affected by societal issues. An example Porter and Kramer (2011) provide is plastic packaging. Through decreasing plastic packaging, a company contributes less to pollution, global warming, etc. At the same time, it also uses fewer resources to wrap its products, has lower disposal fees given that there is less plastic to dispose of, has smaller orders of plastic packaging, etc. The same can be said of being more energy efficient in the value chain-something that is better for the environment and for the bottom line of the company (Porter \& Kramer, 2011). In the food system, this can mean creating compostable or recyclable packaging, using renewable energy to process or package food, and even sourcing more locally to decrease a company's carbon footprint. The food industry pays attention to sustainability and packaging, but recently, it has become quite concerned with food waste. For example, in order to mitigate produce waste, Loblaw has introduced an "ugly duckling" line of fruits and vegetables that are considered imperfect produce. Instead of using this imperfect produce for processing or disposing of it, Loblaw has opted to sell it at a discount. Redefining productivity can also mean creating educational programs for a food company's suppliers which has been a popular strategy especially amongst coffee and cocoa sourcing companies.

The last component of developing social value is building supportive clusters around the business location. This involves developing strong supply chain networks with supporting businesses, suppliers of products and services, and other infrastructure (Porter \& Kramer, 
2011). The authors argue that these draw not only on other businesses, but also on academic and trade communities. Having sustainable and effective clusters within the firm's surroundings better connects it with the community, and increases productivity. If we take the example of Chipotle again, local food sourcing has become a strategic move to shorten the supply chain. This creates shared value through generating profit and employment for local producers while at the same time benefits the company which does not have to source produce from distant places. Other examples include hosting community food workshops or creating educational programs for consumers to learn about healthy eating. The company's successes become the community's and vice versa (Porter \& Kramer, 2011).

Proponents of CSV argue that CSV focuses on creating capital and profits with a social purpose that will allow capitalism to function at a higher level and provide increasing opportunities for profitable success and innovation. The best opportunities for CSV for companies will inevitably be tied with things they already value or are closely tied with their business. This is a vision that is not intended to take away from business, from economic competition, capitalism or any form of profit. It is one that is seen as complimentary and fundamentally integrated with the future of capitalism (Porter \& Kramer, 2011).

\section{Corporate social responsibility: Skeptical perspective}

A different perspective on CSR is the very opposite of the first-a skeptical approach. This means that any participation in CSR efforts is solely underlined by the financial considerations and economic well-being of business. There is therefore no genuine will to support any social or environmental causes beyond the positive ramifications for business' self-interest. This perspective is grounded in the understanding of neoliberalization and the subsequent capital exploitation that had transformed the market and led to new strategies increasing capital accumulation. This section identifies two general approaches as antibusiness views of CSR: the search for legitimacy, as well as increasing profits.

\section{Seeking legitimacy}

The first analytical approach proposed to understand industry's increased participation in NTCFIs, involves the need for increased legitimacy in the food industry to maintain current power configurations. Castelló and Lozano (2011) claim that corporations have been seeking more legitimacy, especially moral legitimacy, through various CSR efforts. It is being used as a tool to legitimize business activity due to an increase in disagreements with stakeholders (Heyder \& Theuvsen, 2008).

Legitimacy influences the way in which people act towards organizations, as well as how they understand and view them (Suchman, 1995, p. 575). Legitimacy can be defined as “...a generalized perception or assumption that actions of an entity are desirable, proper, or appropriate within some socially constructed system of norms, values, beliefs, and definitions” (Suchman, 1995, p. 574). Legitimacy of a given organization therefore is based 
on the perception of observers that identify congruence between the actions and behaviours of an institution, and their own values, norms, beliefs, and expectations (Palazzo \& Scherer, 2006, p. 71). This reflects a neo-institutionalist perspective of the corporation as an embedded institution in society that attempts to align itself with societal norms and expectations in order to continue existing (DiMaggio \& Powell, 1991).

Corporate legitimacy more specifically, looks at the role of business in society (Palazzo \& Scherer, 2006, p. 72). For a few decades now, corporations have been scrutinized by non-governmental organizations (NGOs), and as such, have been in conflict with civil society (Palazzo \& Scherer, 2006; Rayman-Bacchus, 2006). These conflicts have not only endangered the reputations of particular firms, but have sparked critical questions about the role of business in society, and undermined the public's trust in corporate integrity and morality (Palazzo and Scherer, 2006). Without legitimacy, corporations lose power in society (Mitchell, 1986).

Suchman (1995) identifies three general types of organizational legitimacies: pragmatic, cognitive, and moral. Pragmatic legitimacy is grounded in the self-interest of the organization's audience. If the corporation acts and behaves in a way that benefits the audience, then it is considered legitimate. Pragmatic legitimacy is attained through lobbying, branding, and strategic public relations. Cognitive legitimacy is a sub-consciously granted legitimacy (Palazzo \& Scherer, 2006), where the audience sees the organization and its actions as inevitable and necessary, making it very difficult for an organization to influence this type of legitimacy (Suchman, 1995). It is achieved through "shareholder-value ideology, free and open market narratives...” (Palazzo \& Scherer, 2006, p. 78). However, Palazzo, \& Scherer (2006) argue that all of the methods and venues used to achieve pragmatic and cognitive legitimacy have experienced growing opposition from various civil society actors and social movements (p. 78). As such, industry requires moral legitimacy for social acceptance, since the two remaining legitimacies have been waning. Moral legitimacy is normative, based on whether the organization is perceived as doing "the right thing", and if it benefits society as a whole. It is therefore the most important type of legitimacy for corporations to strive for in present society (Palazzo \& Scherer, 2006).

Corporate actors often use discourse, storytelling and symbolism to appeal to certain values and frame certain issues. This creates authority on the basis of legitimate argumentation and protection of the public good, constructing moral legitimacy through CSR actions (Fuchs \& Kalfagianni, 2009, p. 255). These ideas can be considered as reinforcing and legitimizing corporate actors' actions in the food system through discourse. As Fuchs and Kalfagianni (2009) argue, in the case of retailers in the food system, discursive power is the most important force used to achieve legitimacy. Discursive power “....is seen to be a function of norms, ideas, and societal institutions. It is reflected in discourse, communicative practices, and cultural values” (Fuchs \& Lederer, 2007, p. 8), thus working largely with language and ideology. This power can inhibit the existence of certain interests or conflicts appearing on the policy agenda (p. 9), as well as make other interests and values appear legitimate (p. 10). Corporate actors are now spending more time and resources on shaping and defining particular issues (Fuchs, 2005, p. 789). Various animal welfare and food literacy initiatives can be considered as attempts to gain moral legitimacy, showing that industry is 
"doing the right thing”, while creating the consent needed to continue the current power configurations of the food system.

As such, this perspective argues that industry's recent involvement with NTCFIs through CSR can be viewed as a way to reinforce the declining moral legitimacy of corporate food actors. Often, the type of discourse used on packaging, in mission statements and in programs that businesses provide through CSR efforts aligns well with the ideas of food movements looking for healthy, just, and sustainable food systems.

\section{Increasing profit}

Generally, under this perspective, CSR is viewed as "strategic CSR". That is, a "profit maximizing strategy" that may be considered by some as socially responsible (Baron, 2001, p. 17). Under this perspective, the final responsibility of the firm is not to its broad base of stakeholders, but to its shareholders who require the maximum return on their investment. Coors and Winegarden (2005) maintain that a business focusing on pleasing its broad base of stakeholders, rather than its shareholders will not be financially successful. If a company is engaged in non-profitable CSR it “... would either lower company profits, raise prices, lower wages, lower the number of employees hired, or a combination of all four” (p.11). This, however, does not happen, they argue, if a firm's CSR is set up to be profitable, or one that consumers are willing to pay for. For this reason, firms will only engage in CSR if it is profitable for them and increases their market share. This perspective broadly draws on CSR for profit creation rather than generating societal value by focusing on product differentiation, advertising, and greenwashing.

Not only can CSR be used to increase a company's legitimacy, but it can also be used to increase its profit by differentiating itself from other firms (Pollach, 2015). Coors and Winegarden (2005) argue that voluntary CSR is nothing more than an opportunity to advertise and sell new products with new features. CSR can create this differentiation of products through “.... bundle of valuable, rare, in-imitable, and non-substitutable resources, such as processes, equipment, knowledge, capabilities, attributes, and unique corporate cultures" (Pollach, 2015, p. 60).These unique characteristics can create a positive reputation for the firm, recognizing it as a trailblazer, a first mover, or as a thought leader (Pollach, 2015). A positive reputation creates a competitive advantage for the firm. Companies can use CSR as a substitute for advertising, and so the decision to engage in CSR becomes a marketing decision (Coors \& Winegarden, 2005).

Similar to advertising and product differentiation, greenwashing is also a way in which companies use CSR to boost profits (Alves, 2009). Greenwashing occurs when companies develop environmentally friendly processes, attributes, and contribute to charities that have to do with creating a greener world. Although greenwashing largely focuses on environmental issues, its approach relates to companies engaging in social causes as well. Greenwashing is thought to be a tactic used by business for “...branding, public relations, and legal value” (Alves, 2009, p. 2). Alves (2009) argues that through sustainability and environmental CSR, corporate actors continue to be more interested in their bottom line through the quantification of their "green” behaviour, with a fundamental goal of increasing 
profits. Through engaging in CSR and aligning oneself with the values and concerns of society, firms not only create and retain consumer loyalty (Alves, 2009), but also build their reputation as a responsible business, promoting a positive corporate reputation. Green marketing or the advertising of the firm's CSR activities attempts to sell "...the desirable ideas, emotions, and/or experiences” (p. 5) of living an eco-lifestyle.

CSR can help companies differentiate their products by giving it different attributes that are attractive to consumers, or by engaging the firm in specific campaigns. This can generate positive perceptions of a firm engaging in CSR, especially for a first-mover which is perceived to be sincerer in its CSR actions rather than late adopters who are seen as imitators (McWilliams \& Siegel, 2011). CSR is a way for companies to create profit through the provision of some kind of public good to attract customers that value specific attributes, such as eco-labelling (Bagnoli \& Watts, 2003, p. 439).

This perspective of CSR maintains that CSR is nothing more than a tool to boost profits for a firm, where any societal benefits are considered by-products and afterthoughts. This is seen in the food system in various ways: environmental or social certification and labelling (including animal welfare), developing and following various codes of conduct, or attempts to educate the public about healthy eating, cooking, or the food system in general.

\section{A third approach?}

Different ideological stances on CSR were explored in this paper with regards to how they can make a difference in the way industry is seen to be interacting with social and environmental issues. Generally, there are two approaches when looking at industry's involvement in these matters which were outlined above: optimistic and pessimistic. Could there be a third approach, one which considers an area in between a positive and negative view of CSR?

It is obvious that industry is not an innocent bystander in the food system, and that many issues the system is experiencing have developed because of industry's production methods and business practices. Some may argue that solutions without corporate involvement can be difficult, but there are also dangers of co-optation and greenwashing. Likewise, concerns around conflict of interest exist when industry engages in NTCFIs. In areas such as food literacy, CSR can run counter to a company's bottom line. For example, a company such as Hellmann's specializing in the production of mayonnaise (generally not considered a healthy food product), a company which is also owned by Unilever (producing many processed and unhealthy food) developing a food literacy program shows conflicts of interest. It is contradictory to produce and sell unhealthy food while encouraging healthy eating. This predicament may prompt some to completely reject the idea of having industry involved in any food system change. However, given the resources and power corporate actors possess, it may be wise to include them as part of the solution. Instead of dismissing their involvement, mechanisms need to be developed to engage industry at arm's length. This can be done by keeping industry in check with the help of other partners that are accountable to the public (i.e. government and civil society). 
Many companies are increasingly becoming aware of the structural issues of the accumulation process and realize that if they do not deliver change, they will cease to exist. The food industry is not against food system change; however, it does want to continue to benefit economically. Corporate food actors are finally realizing that they need to alter the way they do business. This may be a strategic moment for food system change of which other, less powerful actors, should take advantage. Civil society has become a very important player in pressuring corporations to limit their negative impacts on society in addition to engaging with many social and environmental issues (Gunningham, Gagan, \& Thornton, 2004). It can become an actor that disrupts a potentially industry dominated renegotiation of the food system.

Some authors (Hamann \& Acutt, 2003) suggest that strategic partnerships between business and civil society can occur through tripartite partnerships between civil society, corporate actors, and government. Tripartite partnerships, or multi-stakeholder partnerships, are networks of public and private actors, often between the government (or supranational institutions), civil society, and business. Like policy networks, these actors come together to collaborate on a common approach to solve an issue that affects all of them and is too complex to be solved by one actor alone (Roloff, 2008). Civil society can act as a mechanism to balance interests in the tripartite partnership, and the catalyst needed to disrupt the current food system to create meaningful change.

Developing multi-stakeholder partnerships may also help open communication channels between food actors that rarely or never interact. These partnerships may also help food actors move beyond what Clapp (2016) describes as an impasse based on a binary food policy debate. This is a debate that is polarized because of different manners of communication, vocabularies, values, goals, languages, and ideologies. It has prevented the creation of a crucial "middle ground consensus" needed to move forward in the development of a more just and healthy food system. Developing and fostering genuine partnerships and open discussions may help food actors from different positions of the debate embrace the complexity involved in the food policy space.

\section{Conclusion}

Several crises in the global food system are emerging as a result of the practices in the current food regime. Many of these crises include social and environmental issues-areas with which industry actors tend not to engage. However, this paper argues that industry actors are becoming increasingly involved in these matters, identified here as non-traditional corporate food initiatives (NTCFIs). A few examples were identified at the firm level which tended to concentrate on animal welfare and food literacy.

Two perspectives were presented as ways in which corporate involvement in NTCFIs can be better understood. The first was an optimistic approach to business engaged in NTCFIs through CSR; it included two avenues: corporate citizenship, and creating shared value. The second perspective involved a skeptical outlook on corporate engagement in NTCFIs by looking at ways in which it helps business create and maintain legitimacy, as well 
as how it helps business boost profits. Following this binary debate of CSR, a "grey" approach was presented, one that lay between both the optimistic and pessimistic perspectives. It considered the dangers of including industry in food system change, but also discussed critical motivations for its inclusion.

This review paper focused on analytical perspectives involving corporate engagement in CSR, especially relating to NTCFIs. Bringing business language used by industry and business scholars into food studies can help bridge the divide between food studies and business. It can further develop the interdisciplinarity of the field, as well as equip food studies scholars with new conceptual tools to examine food policy and governance. Food policy and governance scholarship could benefit most from this review by considering changes in the way policy actors, especially private corporate actors govern in the food system.

Many social and environmental issues in the Canadian food system are, to date, not being adequately addressed (if at all) by government. Considering different positions on corporate engagement in the food system can provide future governance outlooks, offering clues as to how and why state and non-state actors will engage with policy. Brownell and Warner (2009) discuss the tobacco industry; however, their argument rings true for the food system. They state that "Whether, and how much, the industry chooses to respond in a responsible manner will determine whether, and how much, formal governmental regulation of industry behavior will be required to redress challenges to the public's health posed by industry products and marketing behaviors” (p. 264). Canada is at the cusp of a changing approach to food policy and governance. If government is waiting on industry to make the first move in remedying many of these food system issues, the government's involvement will depend on industry's (and civil society's) continued engagement in NTCFIs. This will, to a certain extent, determine the future governance model of the Canadian food system.

There is need for more empirical research in the area of food industry and CSR, especially focusing on the impact this engagement has not only on the future of policymaking, but also on the creation of new industry benchmarks in the food system. More research also needs to be done regarding how civil society fits into this picture, as well as how it fits into a tripartite partnership that is able to work towards a more sustainable and just food system.

\section{References}

Alves, I. (2009). Green spin everywhere: How greenwashing reveals the limits of the CSR paradigm. Journal of Global Change and Governance 11(1), 1-26.

Auld, G., Bernstein, S., \& Cashore, B. (2008). The new corporate responsibility. Annual Review of Environment and Resources 33, 413-435.

Baertlein, L. (2012, April 25). Burger King pledges to end use of caged pigs, hens. Reuters. Retrieved from http://www.reuters.com/article/2012/04/25/burgerkinganimalwelfare-idAFL2E8FOLJ220120425 
Bagnoli, M., \& Watts, D. (2003). Selling to socially responsible consumers: Competition and the private provision of public goods. Journal of Economics \& Management Strategy 12(3), 419-445.

Baron, D. (2001). Private politics, corporate social responsibility, and integrated strategy. Journal of Economics \& Management Strategy 10(1), 7-45.

Bevir, M. (2012). Governance: A very short introduction. Oxford, UK: Oxford University Press.

Brownell, K, \& Warner, K. (2009). The perils of ignoring history: Big tobacco played dirty and millions died: How similar is big food? The Milbank Quarterly 87(1), 259-294.

Burch, D., \& Lawrence, G. (2005). Supermarket own Brands, supply chains and the transformation of the agri-food system. International Journal of Sociology of Agriculture and Food 13(1), 1-18.

Carroll, A. (1998). The four faces of corporate citizenship. Business and Society Review 100/101, 1-7.

Castelló, I., \& Lozano, J. (2011). Searching for new forms of legitimacy through corporate responsibility rhetoric. Journal of Business Ethics 100(11), p. 11-29.

Chandler, D. (2014). Corporate social responsibility: A strategic perspective. Retrieved from http://www.eblib.com.

Chipotle. (n.d.). Food with integrity. Retrieved from https://chipotle.com/food-withintegrity.

Chipotle. (2015). Press release: Chipotle becomes the first national restaurant company to use only non-GMO ingredients. Retrieved from http://ir.chipotle.com/phoenix.zhtml?c=194775\&p=irol-newsArticle\&ID=2040322

Clapp, J. (2016). Big thinking lecture: Navigating the global food fight: Trade, food security and the battle for policy space [video]. Retrieved from http://congress2016.ca/program/events/clapp

Coors, A., \& Winegarden, W. (2005). Corporate social responsibility - Or good advertising? Regulation (Spring), 10-11.

DiMaggio, P., \& Powell, W. (Eds.) (1991). The new institutionalism in organization analysis. Chicago, IL: University of Chicago Press.

Donaldson, T., \& Preston, L. (1995). The stakeholder theory of the corporation: concepts, evidence, and implications. The Academy of Management Review 20(1), 6591. 
Freeman, R., Harrison, J., Wicks, A., Parmar, B., \& de Colle, S. (2010). Stakeholder theory: The state of the art. Cambridge: Cambridge University Press.

Fuchs, D. (2005). Commanding heights? The strength and fragility of business power in global politics. Millennium: Journal of International Studies 33(3), 771-801.

Fuchs, D., \& Kalfagianni, A. (2009). Discursive power as a source of legitimation in food retail governance. The International Review of Retail, Distribution and Consumer Research 19(5), 553-570.

Fuchs, D., \& Kalfagianni, A. (2010). The causes and consequences of private food governance. Business and Politics 12(3), 1-34.

Fuchs, D., \& Kalfagianni, A. (2012). The effectiveness of private environmental governance. In P. Dauvergne (Ed.) Handbook of Global Environmental Politics (pp. 298-307). Northampton, MA: Edward Elgar Publishing Inc.

Fuchs, D., Kalfagianni, A., \& Havinga, T. (2011). Actors in private food governance: The legitimacy of retail standards and multistakeholder initiatives with civil society participation. Agriculture and Human Values 28(3), 353-367.

Fuchs, D. \& Lederer, M. (2007). The power of business. Business Power and Global Governance 9(3), 1-17

Gunningham, N., Gagan, R., Thornton, D. (2004). Social license and environmental protection: Why businesses go beyond compliance. Law \& Social Inquiry 29, 307-341.

Hamann, R., Acutt, N. (2003). How should civil society (and the government) respond to 'corporate social responsibility'? A critique of business motivations and the potential for partnership. Development Southern Africa 20(2), 255-270.

Hatanaka, M., Bain, C., \& Busch, L. (2005). Third-party certification in the global agrifood system. Food Policy 30, 354-369.

Havinga, T. (2006). Private regulation of food safety by supermarkets. Law \& Policy 28(4), 515-532.

Havinga, T. (2015). Conceptualizing regulatory arrangements: Complex networks and regulatory roles. In T. Havinga, F. von Waarden \& D. Casey (Eds.), The Changing Landscape of Food Governance: Public and Private Encounters (pp. 19-36). Northampton, MA: Edward Elgar Publishing.

Havinga, T., van Waarden, F., \& Casey, D. (Eds.) (2015). The changing landscape of food governance: Public and private encounters. Northampton, MA: Edward Elgar Publishing.

Hellmann's. (n.d.). Our commitment. Retrieved from http://www.hellmanns.ca/realfoodmovement/detail/115440/our-commitment 
Heyder, M., \& Theuvsen, L. (February, 2008). Legitimating business activities using corporate social responsibility: Is there a need for CSR in agribusiness? Paper presented $10^{\text {th }}$ EAAE Seminar 'System Dynamics and Innovation in Food Networks', Innsbruck-Igls, Austria.

Hillman, A., \& Hitt, M. (1999). Corporate political strategy formulation: A model of approach, participation, and strategy decisions. The Academy of Management Review 24(4), 825-842.

Huffstutter, P.J. (2012, May 31). McDonald's to end pork gestation crate use by 2022. Reuters. Retrieved from http://www.reuters.com/article/2012/05/31/us-mcdonaldspig-crates-idUSBRE84U1FR20120531

Kashty, M. (2014, June 12). Metro's food truck rolls through Québec. Canadian Grocer. Retrieved from http://www.canadiangrocer.com/top-stories/metros-food-truck-rollsthrough-Québec-41783

Kennett, P. (2008). Introduction: Governance, the State and Public Policy in a Global Age. In P. Kennett (Ed.), Governance, Globalization and Public Policy. Northampton, MA: Edward Elgar.

Lang. T. (2003). Food industrialisation and food power: Implications for food governance. Development Policy Review 21(5-6), 555-568.

Matten, D., \& Crane, A. (2005). Corporate citizenship: Toward an extended theoretical conceptualization. Academy of Management Review 30(1), 166-179.

Matten, D., Crane, A., \& Chapple, W. (2003). Behind the mask: Revealing the true face of corporate citizenship. Journal of Business Ethics 45, 109-120.

McDonalds. (n.d.). Issues we're focusing on. Retrieved from http://www.aboutmcdonalds.com/mcd/sustainability/sourcing/animal-health-andwelfare/issues-we-re-focusing-on.html

McWilliams, A., \& Siegel, D. (2011). Creating and capturing value: Strategic corporate social responsibility, resource-based theory, and sustainable competitive advantage. Journal of Management 375), 1480-1495.

Metro. (n.d.a.) FAQ. Retrieved from http://www.metro.ca/products-services/my-healthyplate-with-metro/about/frequently-asked-questions/faq-smiles.en.html

Metro. (n.d.b.) 4 pillars of the program. http://www.metro.ca/products-services/my-healthyplate-with-metro/about/4-pillars-of-the-program.en.html

Mitchell, N. (1986). Corporate power, legitimacy, and social policy. Western Political Quarterly 39(2), 197-212.

Moon, J., Crane, A., \& Matten, D. (2005). Can corporations be citizens? Corporate citizenship as a metaphor for business participation in society. Business Ethics Quarterly 15(3), 429-453. 
Palazzo, G., \& Scherer, A.G. (2006). Corporate legitimacy as deliberation: A communicative framework. Journal of Business Ethics 66, 71-88.

Peters, B.G., \& Pierre, J. (1998). Governance without government? Rethinking public administration. Journal of Public Administration Research and Theory 8(2), 223-243.

Pierre, J., \& Peters, B.G. (2000). Governance, politics, and the state. New York, NY: ST. MARTIN'S PRESS, INC.

Pollach, I. (2015). Strategic corporate social responsibility: The struggle for legitimacy and reputation. International Journal of Business Governance and Ethics 10(1), 57-75.

Porter, M., \& Kramer, M. (2006). Strategy \& society. Harvard Business Review (December), 78-92.

Porter, M., \& Kramer, M. (2011). Creating shared value. Harvard Business Review (January-February), 62-77.

Rayman-Bacchus, L. (2006). Reflecting on corporate legitimacy. Critical Perspectives on Accounting 17, 323-335.

Richards, C., Bjørkhaug, H., Lawrence, G. \& Hickman, E. (2013). Retailer-driven agriculture restructuring - Australia, the UK and Norway in comparison. Agriculture and Human Values 30, 235-245.

Roloff, J. (2008). Learning from multi-stakeholder networks: Issue-focussed stakeholder management. Journal of Business Ethics 82, 233-250.

Scherer, A.G., \& Palazzo, G. (2011). The new political role of business in a globalized world: A review of a new perspective of CSR and its implications for the firm, governance, and democracy. Journal of Management Studies 48(4), 899-931.

Scherer, A.G., Palazzo, G., \& Matten, D. (2014). The business firm as a political actor: A new theory of the firm for a globalized world. Business \& Society 53(2), 143-156.

Sharma, L., Teret, S., \& Brownell, K. (2010). The food industry and self-regulation: standards to promote success and to avoid public health failures. American Journal of Public Health 100(2), 240-246.

Sobeys. (n.d.) Sobeys + Jamie Oliver. Retrieved from http://betterfoodforall.sobeys.com/\#sobeysjamie

Suchman, M. (1995). Managing legitimacy: Strategic and institutional approaches. Academy of Management Review 20(3), 571-610.

Windsor, D. (2006). Corporate social responsibility: Three key approaches. Journal of Management Studies 43(1), 93-114. 